\title{
Low Pathogenic Avian Influenza and Coinfecting Pathogens: A Review of Experimental Infections in Avian Models
}

Author(s): Sajid Umar, Jean Luc Guerin, and Mariette F. Ducatez

Source: Avian Diseases, 61(1):3-15.

Published By: American Association of Avian Pathologists

DOI: http://dx.doi.org/10.1637/11514-101316-Review

URL: http://www.bioone.org/doi/full/10.1637/11514-101316-Review

BioOne (www.bioone.org) is a nonprofit, online aggregation of core research in the biological, ecological, and environmental sciences. BioOne provides a sustainable online platform for over 170 journals and books published by nonprofit societies, associations, museums, institutions, and presses.

Your use of this PDF, the BioOne Web site, and all posted and associated content indicates your acceptance of BioOne's Terms of Use, available at www.bioone.org/page/terms_of_use.

Usage of BioOne content is strictly limited to personal, educational, and non-commercial use. Commercial inquiries or rights and permissions requests should be directed to the individual publisher as copyright holder. 


\title{
Review Article
}

\section{Low Pathogenic Avian Influenza and Coinfecting Pathogens: A Review of Experimental Infections in Avian Models}

\author{
Sajid Umar, Jean Luc Guerin, and Mariette F. Ducatez ${ }^{\mathrm{A}}$ \\ IHAP, Université de Toulouse, INRA, ENVT, 23 Chemin des Capelles, 37076 Toulouse, France
}

Received 14 October 2016; Accepted 7 November 2016; Published ahead of print 17 November 2016; Published March 2017

\begin{abstract}
SUMMARY. Low pathogenic avian influenza virus (LPAIV) usually causes mild disease or asymptomatic infection in poultry. LPAIV has, however, become a great threat to poultry industry due to mixed infections with other pathogens. Coinfections do frequently occur in the field but are not easily detected, and their impact on pathobiology is not clearly defined due to their complicated nature, but it is well known that there is an impact. One way to increase our knowledge of coinfections in poultry is to challenge birds in experimental and controlled conditions. While many articles report in vivo experiments with LPAIV in avian models, only a few have studied coinfections. Moreover, researchers tend to choose different bird types, ages, inoculation routes, and doses for their experiments, making it difficult to compare between studies. This review describes the state of the art for experimental infections with LPAIV alone or associated with coinfecting pathogens in avian models. It also discusses how best to mimic field infections in laboratory settings. In the field of avian diseases, experimental design is obviously directly linked with the research question addressed, but there is a gap between field and experimental data, and further studies are warranted to better understand how to bring laboratory settings closer to field situations.
\end{abstract}

RESUMEN. Estudio Recapitulativo. Influenza aviar de baja patogenicidad y patógenos co-infectantes: Revisión de las infecciones experimentales en modelos aviares.

Los virus de la influenza aviar de baja patogenicidad (con las siglas en inglés LPAIV) generalmente causan enfermedad leve o infección asintomática en las aves comerciales. Sin embargo, los virus de la influenza aviar de baja patogenicidad se han convertido en una gran amenaza para la industria avícola debido a infecciones mixtas con otros patógenos. Las co-infecciones ocurren con frecuencia en el campo pero no son detectadas fácilmente y su impacto en la patobiología de estos virus no está claramente definido debido a su naturaleza complicada, pero se reconoce que existe un impacto. Una forma de aumentar el conocimiento de las coinfecciones en las aves comerciales es desafiar a las aves en condiciones experimentales y controladas. Mientras que muchos artículos reportan experimentos in vivo con virus de la influenza aviar de baja patogenicidad en modelos aviares, sólo unos pocos han estudiado co-infecciones. Además, los investigadores tienden a elegir diferentes tipos de aves, edades, rutas de inoculación y dosis para sus experimentos, lo que dificulta las comparaciones entre los estudios. Esta revisión describe lo más reciente con las infecciones experimentales con virus de la influenza aviar de baja patogenicidad, solos o asociados con patógenos de co-infectantes en modelos aviares. También se analiza la mejor manera de replicar las infecciones de campo en condiciones de laboratorio. En el campo de las enfermedades aviares, el diseño experimental está obviamente relacionado directamente con la hipótesis de investigación abordada, pero existe una brecha entre los datos experimentales y de campo y se necesitan más estudios para comprender mejor cómo adecuar los parámetros de laboratorio a las situaciones de campo.

Key words: low pathogenic avian influenza viruses, coinfection, avian models

Abbreviations: $\mathrm{AI}=$ avian influenza; $\mathrm{AIV}=$ avian influenza virus; $\mathrm{AP}=$ Avibacterium paragallinarum; $\mathrm{C}=$ intracloacal; $\mathrm{CFU}=$ colony-forming unit; $\mathrm{EID}_{50}=50 \%$ egg infectious dose; $\mathrm{HA}=$ hemagglutination; HPAIV = highly pathogenic avian influenza virus; $\mathrm{IBV}=$ infectious bronchitis virus; $\mathrm{IC}=$ intracloacal; $\mathrm{ID}_{50}=50 \%$ infectious dose; $\mathrm{IM}=$ intramuscular; $\mathrm{IN}=$ intranasal; $\mathrm{IO}=$ intraoviduct; IT = intratracheal; IV = intravenous; LPAIV = low pathogenic avian influenza virus; $\mathrm{MG}=$ Mycoplasma gallisepticum; $\mathrm{NA}=$ neuraminidase; $\mathrm{NDV}=\mathrm{Newcastle}$ disease virus; $\mathrm{O}=$ intraocular; $\mathrm{ORT}=$ Ornithobacterium rhinotracheale; $\mathrm{PO}=$ per orally; $\mathrm{SA}=$ Staphylococcus aureus, $\mathrm{SPF}=$ specific-pathogen-free; $\mathrm{TCID}=$ tissue culture infectious dose; TOC $=$ tracheal organ culture

In poultry farms, infections with avian influenza viruses (AIVs) are dreaded as they are very often associated with severe economic losses. To better understand the clinical outcomes, pathogenesis, and transmission in the field, researchers have developed animal models to study infections in laboratory settings. Here we present a survey of the state of the art for experimental infections with low pathogenic avian influenza virus (LPAIV) alone or associated with coinfecting pathogens in avian models. On this basis we then discuss how to best mimic field infections in laboratory settings and highlight a gap between field and experimental data that requires further studies to fill. This review is not a meta-analysis but was performed using

\footnotetext{
${ }^{\text {A }}$ Corresponding author. E-mail: m.ducatez@envt.fr
}

PubMed and a combination of the following keywords: low pathogenic avian influenza virus, coinfection, chicken, turkey, duck, poultry, experimental infection, in vivo. Only studies with experimental infections of birds with a LPAIV alone or with a coinfecting pathogen were considered here.

\section{AVIAN INFLUENZA VIRUSES: HIGH AND LOW PATHOGE- NICITY}

Avian influenza (AI) is caused by avian influenza viruses (AIVs) that belong to the genus Influenza virus $A$ of the family Orthomyxoviridae. AIV harbors a segmented genome of eight distinct single-stranded RNA molecules, which encode at least 10 
different viral proteins (50). On the basis of antigen variations of the surface glycoprotein hemagglutinin (HA) and neuraminidase (NA), there are 18 antigenically distinct HA and 11 NA subtypes of influenza A viruses (82). With the exception of the recently described influenza A (H17N10 and H18N11) viruses of bats, all other subtypes circulate in birds (84). AIVs are classified into two pathotypes in gallinaceous birds known as a highly pathogenic avian influenza virus (HPAIV) and a low pathogenic avian influenza virus (LPAIV) based on the existing World Organization for Animal Health criteria (16). For AIVs to be highly pathogenic, they must meet one of two criteria: 1) intravenous pathogenicity index $>1.2$ or lethality for $75 \%$ or more of intravenous susceptible chickens (Gallus gallus domesticus) or (2) viruses of $\mathrm{H} 5$ or $\mathrm{H} 7$ subtypes with multiple basic amino acids at the HA cleavage site. All other AIVs are characterized as LPAIVs (78). HPAIVs are responsible for rapid and fatal systemic infection inducing mortality up to $100 \%$ in broilers, layers, and breeders, while LPAIVs lead to asymptomatic or milder infections. All HPAIVs identified up to date belong to $\mathrm{H} 5$ and $\mathrm{H} 7$ subtypes, even though all $\mathrm{H} 5$ or $\mathrm{H} 7$ viruses are not always highly pathogenic (86). Pathogenicity of HPAIVs is associated with polybasic amino acids (arginine and lysine) at their HA cleavage site motif (85), which enable them to replicate and damage a wide range of vital organs and tissues, ultimately resulting in the death of the infected birds (64). In contrast, LPAIVs are capable to replicate only in limited tissues of respiratory and digestive systems. In the field, LPAIVs can cause severe disease if the host is stressed or if other diseases are present $(1,47)$. In cases of subclinical LPAIV infections, production losses are observed due to anorexia in meat birds and drop in egg production in breeders/layers. LPAIVs of H1N1 and H9N2 subtypes were shown to replicate in chicken and turkey reproductive tracts $(57,58,63,83,89)$. In the present review we choose to focus on LPAIVs.

\section{INFLUENZA A VIRUSES AND EVOLUTION}

Because AI RNA-polymerase does not possess a proofreading function, faulty nucleotides are integrated during replication with high mutation rates of $10^{-3}$ to $10^{-4}$ substitutions/site/year. Besides mutations, viruses with segmented genomes change genetically through genetic reassortment (antigenic shift) by exchange of one or more segments between two related viruses that infect a host cell at the same time $(4,6)$. Genetic variability is of vital importance for the survival of AIVs, and it is ensured through mutations (antigenic drift) and reassortment (antigenic shift) during the replication cycle of the virus (26). Infections with multiple strains of AIV are well documented in ducks and lead to a high viral genetic diversity. In contrast, mixed infections in poultry are relatively rare and generally seen in areas where several endemic strains circulate $(1,79)$. In nature, the high prevalence of mixed infections in chickens and ducks can then lead to genome reassortment and result in antigenic shift $(27,59)$. It has been confirmed that genetic reassortment in LPAIVs has led to novel phenotypes and increased virulence $(37,40)$. Previous studies have shown that seven genes of the $\mathrm{H} 5 \mathrm{~N} 1$ virus isolated in the Hong Kong outbreak in 1997 have high sequence similarity to LPAIV virus H6N1 (69). Similarly, in Pakistan extensive cocirculation of H9N2 viruses with other AIVs, including highly pathogenic $\mathrm{H} 5 \mathrm{~N} 1$ and $\mathrm{H} 7 \mathrm{~N} 3$ subtypes, coupled with extensive vaccination has generated a novel variant $\mathrm{H} 9 \mathrm{~N} 2$ with possibly increased epizootic and zoonotic potentials (51). The novel H9N2 viruses (A/chicken/Pakistan/UDL-01/08-like virus) currently circulating in Pakistan have acquired PB2, PB1, PA, and NS gene segments from $\mathrm{HPAI} \mathrm{H} 7 \mathrm{~N} 3$ viruses with the other genes originating from G1-like lineage H9N2 viruses (40). Some LPAIVs, such as H9N2, can indeed break species barriers and provide genes to other influenza virus, which could present a risk for severe human infection (31).

\section{LPAIVS AND COINFECTING PATHOGENS IN FIELD CON- DITIONS}

Over the last 15 years, influenza viruses of the H9N2 subtype have been isolated from outbreaks in poultry in various countries such as Germany, Italy, Ireland, Saudi Arabia, Iran, Egypt, Israel, Pakistan, China, Hong Kong, South Africa, and the United States $(1,2,7,16)$. Laboratory examination of specific-pathogen-free (SPF) chicken showed that H9N2 avian influenza virus causes little disease, but in the last decade Asian and Middle Eastern countries have faced frequent outbreaks of H9N2 infection with high mortality $(8,31)$. It was reported that outbreaks of $\mathrm{H} 9 \mathrm{~N} 2$ influenza viruses in Iranian broiler chicken farms caused a 20-65\% mortality rate, and the most prominent lesions in affected dead birds were respiratory airway hyperemia and severe exudation, which lead to tubular cast formation in the tracheal bifurcation, extending to the lower bronchi $(52,53,66)$. However, it is also documented that LPAIVs, such as the H9N2 subtype in domestic poultry, manifest mild clinical signs and respiratory diseases with low mortality, not exceeding 5\% (79). Disease effects of AI may be far more devastating in the presence of other organisms or other forms of stress (1). It is proposed that concurrent infections may play a key role in exacerbating mortality in chicken infected with mild AIVs. Coinfection with other respiratory pathogens may complicate the respiratory disease syndrome during outbreaks of non-highly pathogenic avian influenza viruses and cause severe disease and high mortality. Strains of infectious bronchitis viruses (IBVs) were isolated from several broiler flocks during the course of the H9N2 outbreak in Iran (55). Previous studies demonstrate that H9N2 virus infection contributes to respiratory distress and is involved in diseases caused by other respiratory pathogens in the poultry industry $(36,79)$. Mixed infections of influenza virus with other respiratory pathogens have been found to be responsible for high mortality and resulted in great economic losses $(1,8,29,49)$. Mixed infections with Newcastle disease virus (NDV) and LPAIVs have been reported in waterfowl, and competition between viruses during isolation suggests an underestimation of coinfections in the laboratory (24).

Other respiratory copathogens, such as Mycoplasma gallisepticum (MG), Escherichia coli, and IBV, have been commonly identified in the field and could have increased the severity of clinical syndromes accompanying H9N2 AI virus infections (70). MG and E. coli were isolated from the field cases and may have played a role as copathogens to AI virus in the clinical disease syndrome. Fibrinonecrotic casts in the tracheal bifurcation were reported in turkeys during the 1999 outbreak of H7N1 AI in Italy in association with secondary bacterial pathogens such as E. coli, Riemerella anatipestifer, and Pasteurella multocida (17). MG in combination with other respiratory pathogens, including LPAIVs, can cause severe airsacculitis $(9,10,53)$. This suggests a common pathogenic mechanism 
with multiple lineages of AIVs causing extensive damage to respiratory airways, followed by additional damage by secondary pathogens. In severe cases, death was perceived as the result of occlusion of the airway and resulting asphyxiation. The individual role of H9N2 AI virus and copathogens needs to be determined in future studies.

\section{LPAIVs IN EXPERIMENTAL STUDIES}

The pathogenicity and transmission of many LPAIV strains have been investigated in experimental conditions in avian models. SPF chickens are the most frequently used as a standard wellcharacterized and relatively homogeneous host to carry out LPAIV experimental infections. Table 1 summarizes the main experimental infections of avian species with LPAIVs. Considering that different research teams used various animal models (in term of species and age), LPAIV strains, routes of inoculation, and doses, Table 1 illustrates the difficulty one may have to compare data generated from different studies.

Avian models of 3-4 wk of age are commonly used for experimental studies, likely because of their easy handling and low feed cost at this age. Moreover, the intranasal route (IN) for the inoculation of respiratory pathogens in avian models is the most common followed by intratracheal (IT), per orally (PO), intraocular (O), intramuscular (IM), intravenous (IV), intraoviduct (IO), and intracloacal $(\mathrm{C})$. The aerosol route is the most common route for the spread of respiratory pathogens, which is why many researchers choose IN or IT routes to simulate respiratory transmission of LPAIV and complicating pathogens. Inoculation routes (IN, IC, and O) were compared in a study where hens were inoculated with $10^{6}$ $\mathrm{EID}_{50}$ of $\mathrm{A} /$ chicken/CA/1255/02(H6N2) or A/chicken/NJ/12220/ 97(H9N2). Hens inoculated IN with H6N2 virus presented mild clinical signs and shed higher virus titers in the higher respiratory tract (as measured in oropharyngeal swabs) than their H6N2inoculated counterparts. Birds were less susceptible to H9N2, which was detected only in oropharyngeal swabs and only when inoculated IN. Clinical signs and lesions were also less pronounced when the pathogen was inoculated through oral and cloacal routes (57). In this latter study the IN route of inoculation was hence the most efficient. But it may be virus strain-specific and linked with preferential binding of these $\mathrm{H} 6 \mathrm{~N} 2$ and $\mathrm{H} 9 \mathrm{~N} 2$ viruses to the respiratory rather than digestive tract of the chickens.

As far as inoculation dose is concerned, the most common dose used in experimental studies is $10^{6}$ EID $_{50}$ for LPAIVs, and this dose usually induces clinical signs and lesions. The latter are indeed dose dependent. Thus, quail and turkeys infected oro-nasally with increasing doses $\left(10^{3}-10^{6} \mathrm{EID}_{50} / 0.1 \mathrm{ml}\right)$ of LPAIV (A/quail/Hong Kong/G1/97) showed more disease and lesions when inoculated with higher virus doses. Quail were more susceptible than turkeys; they were readily infected with lower challenge doses (13).

Ex vivo tracheal organ culture (TOC) models have been proposed as possible alternative to experimental LPAIV infections of the respiratory tract to address some specific questions: TOC may be of interest to compare the host susceptibility to different LPAIV strains by monitoring induction of ciliostatis, necrosis of the epithelium, or viral replication (61). But tissue cultures show obvious limitations since they cannot address accurately the contribution of the immune response.

\section{LPAIVS AND COINFECTING PATHOGENS IN EXPERIMEN- TAL STUDIES}

It is well appreciated that upper respiratory tract viral infections in poultry are often complicated by more serious bacterial diseases. While influenza virus is most commonly thought of in this context, other respiratory viruses, including NDV, IBV, and infectious laryngotracheitis virus, may also predispose to secondary infections. Several different bacteria have also been implicated, including MG, E. coli, Avibacterium paragallinarum, Ornithobacterium rhinotracheale (ORT), and Staphylococcus aureus (SA) (35,36,77). It is thought that certain pairings of organisms better complement each other than other potential pairings. Coinfections of poultry present a complicated clinical picture confusing the identification and diagnosis, and unfortunately little is known on the interactions between coinfecting pathogens (19). Tables 2 and 3 summarize the literature on experimental infections of birds with LPAIVs and bacteria, and LPAIVs and avian viruses, respectively. Coinfection of poultry with more than one bacterial and/or viral agent is common and often results in increased clinical signs when compared to singleagent infections $(56,73,74)$. Conversely, infection of a host with one virus may affect infection by a second virus, a phenomenon explained by the occurrence of viral interference; cells infected by a virus may not permit multiplication of a second virus (22). In addition, viral interference may be detrimental to detecting viruses in coinfected flocks since lower or undetectable virus titers might fail to give a complete diagnosis (24). Coinfection of LPAIV A/chicken/ Iran/SH-110/99 (H9N2) with infectious bronchitis live vaccine led to increased clinical signs and mortality rates as well as longer virus shedding in chickens (36).

Significantly higher antibody titers against AIV was observed during coinfection with IBV, which may indicate that IBV could promote the propagation of H9N2 AIV (A/chicken/Iran/SH110/ 99(H9N2)) or stimulate the immune response (67). IBV and LPAIV coinfections have not been thoroughly studied, but live attenuated IBV vaccine has been shown to interact with LPAIV H9N2 infection, leading to a more severe disease outcome than with LPAIV alone $(35,36)$. Coinfection of LPAIV A/mallard/MN/ 199106/99(H3N8) and NDV (mallard/US(MN)/AI06-978/2006) in ducks resulted in a higher number of cloacal swabs detected positive for LPAIV and a lower number of cloacal swabs detected positive for NDV (25). Coinfection of chickens and turkeys with NDV and LPAIV (A/turkey/VA/SEP/67/2002(H7N2) affected the replication dynamics of these viruses but did not alter clinical signs (19). ORT infection could lead to a higher mortality and economic losses in presence of H9N2 AIV in chicken (56). Coinfection of $\mathrm{H} 9 \mathrm{~N} 2$ influenza virus with SA or $A$. paragallinarum enhances the replication of the virus in chickens, resulting in exacerbation of the H9N2 virus infection (42). Bacterial and viral infections cause huge economic losses in the form of morbidity and mortality of birds. Poor diagnosis, antibiotics, and vaccination cost for the prevention or treatment of viral and bacterial infections (and emergence of antibiotics-resistant bacteria) are major issues for poultry industry. The medical community has expressed concern that antibiotic use in food animals may promote the development of antibiotic-resistant strains of bacteria that could impact human health too (32). Antibiotic resistance is also an economic burden on the health care system. This global trend toward restriction of antibiotics use in poultry farms may lead to an increase of bacterial coinfections and 


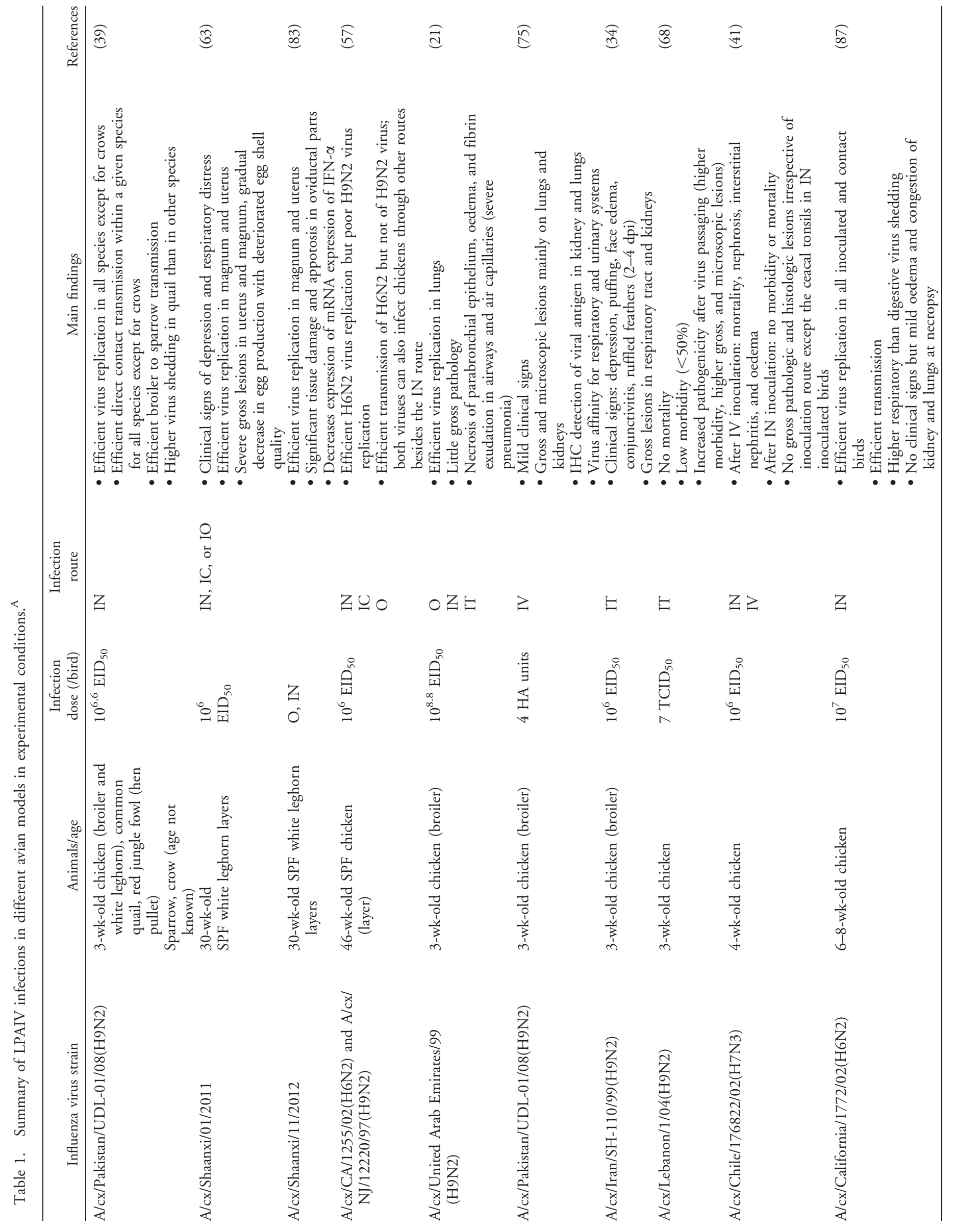


Coinfections in avian models

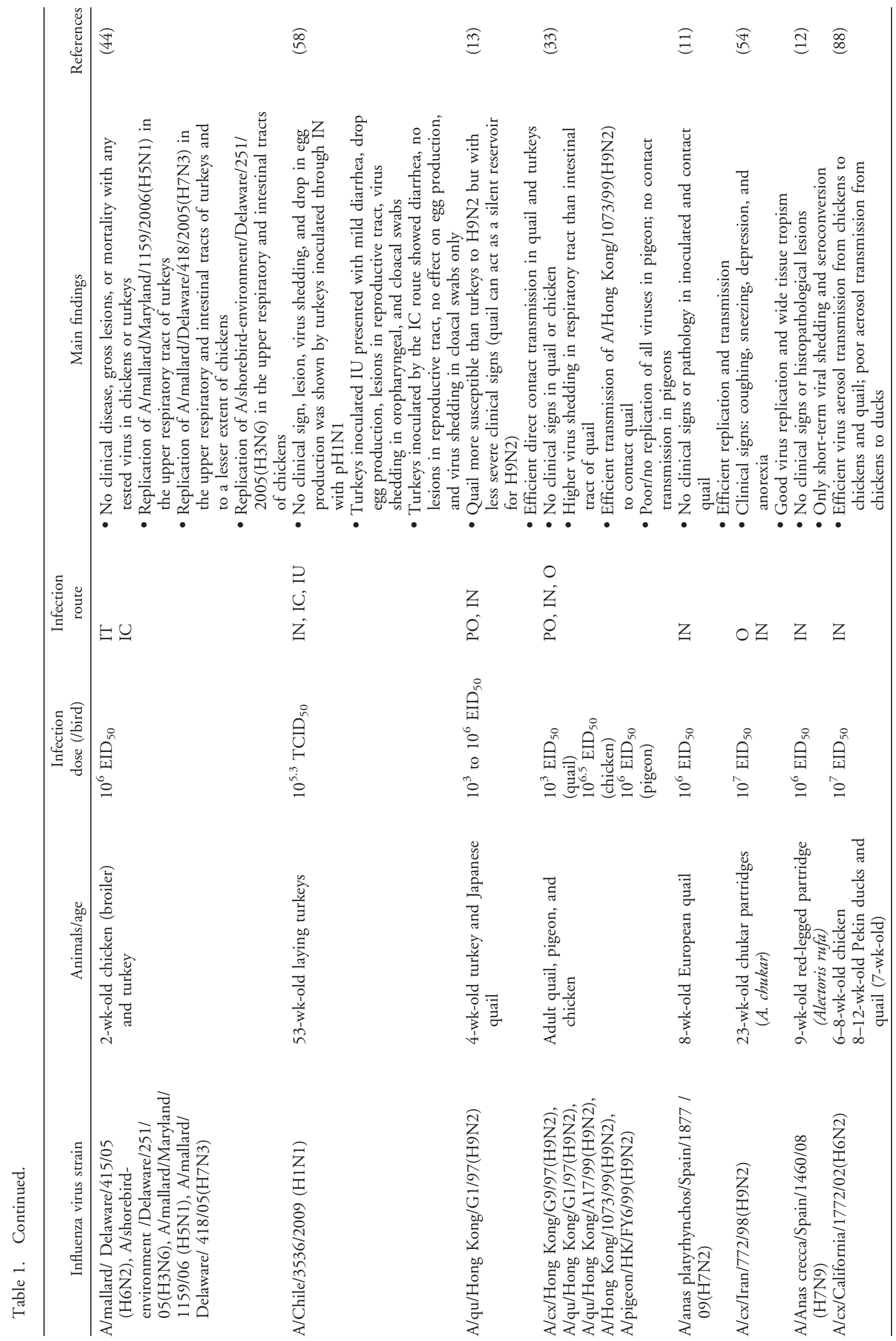




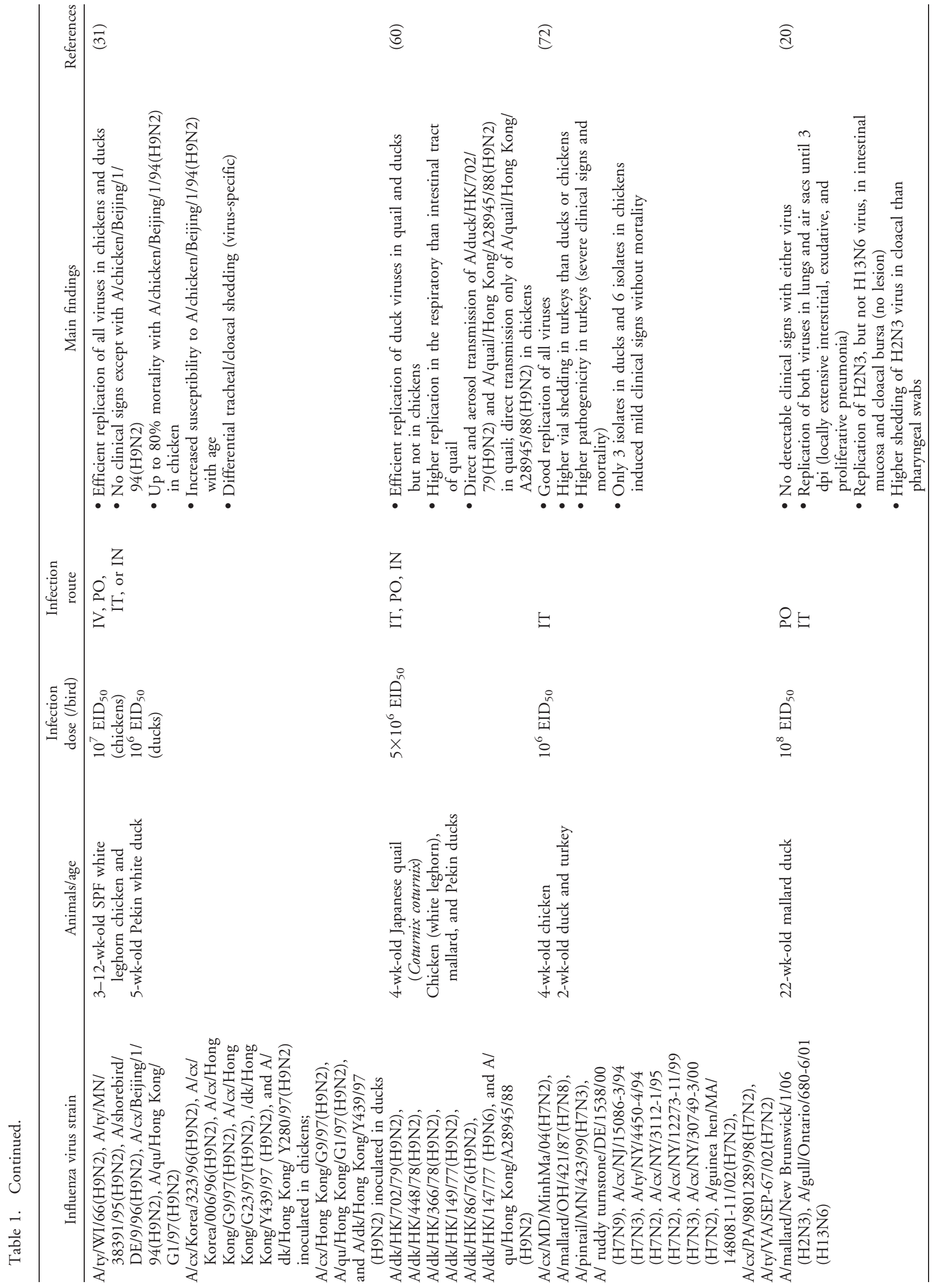


stresses the need for better understanding of these complex interactions in vivo to define innovative approaches of control.

As for LPAIV infections alone, the most common avian models for the study of viral and bacterial coinfections are chickens. Ducks, turkeys, quail, and partridges have also been used to address different research questions. One possible reason for the most widely use of chicken as an avian model may be their easy handling, availability, low price, and early maturity as compared with other avian models. In addition to this, chickens are also the most economically important (largest industry) type of poultry worldwide.

The classical doses used for bacteria inoculation (MG, E. coli) as described in literature are $10^{6}$ to $10^{9}$ colony-forming units (CFUs). Clinical signs and lesions severity have been shown to increase in a dose-dependent manner. Bacterial coinfections lead to more severe lesions when the bacterial were inoculated IN or via an aerosol route. In an experimental coinfection study with LPAIV H3N8 (A/ mallard/Hungary/19616/07) and MG inoculated through aerosol spray, the authors showed that LPAI H3N8 virus alone did not cause any clinical signs, but MG infection caused clinical signs, reduction of body weight gain, and colonization of the inner organs. These parameters were more severe in the birds coinfected with MG and LPAIV H3N8 than in the group challenged with MG alone. Coinfection with LPAIV H3N8 thus enhanced the pathogenesis of MG significantly $(73,74)$. Barbour $e$ t al. coinfected chickens IT or intrathoracically with H9N2 LPAIV and E. coli. High and acute mortality was observed with the intrathoracic inoculation route for E. coli $(9,10)$.

LPAIV coinfection with other viruses promotes replication of LPAIV, leading to increase the severity of clinical signs, mortality rate, and gross lesions $(35,67)$. However, these viruses can interfere during viral replication phase as reported in previous studies. França and colleagues documented higher shedding of LPAIV in cloacal swabs when mallards were coinfected with LPAIV and NDV on the same day. Conversely, marked reduction of NDV in cloacal swabs was observed during the study. At the same time, reduced LPAIV and NDV was observed in oropharyngeal swabs. However, coinfection with LPAIV and NDV did not affect replication of LPAIV (H3N8) in intestine and bursa of Fabricius. Viral interference during replication can be a possible reason for the decrease of NDV shedding in cloacal swabs, and LPAIV may have reduced or inhibited NDV replication (25). Similarly, CostaHurtado and colleagues reported that coinfection of chicken and turkeys with LPAIV (H7N2) and NDV can affect replication dynamics of these viruses but did not affect clinical signs. This virus replication pattern was dependent on timings of inoculation and bird species, suggesting that coinfection with two different viruses can result in temporary cell receptor binding competition (19). During this study, chickens and turkeys were infected with an NDV vaccine strain (LaSota) and a H7N2 LPAIV (A/turkey/VA/ SEP-67/ 2002) simultaneously or sequentially 3 days apart. No clinical signs were observed in chickens coinfected with NDV and LPAIV, while all turkeys showed mild clinical signs during coinfection. The replication dynamics of these viruses was, however, affected by the coinfection: lower virus titers and fewer birds with virus replication were recorded, especially when LPAIV was followed by NDV. These results suggest that infection with a heterologous virus may result in temporary competition for cell receptors or competent cells for replication, most likely interferon-mediated, which decreases with time (19). 


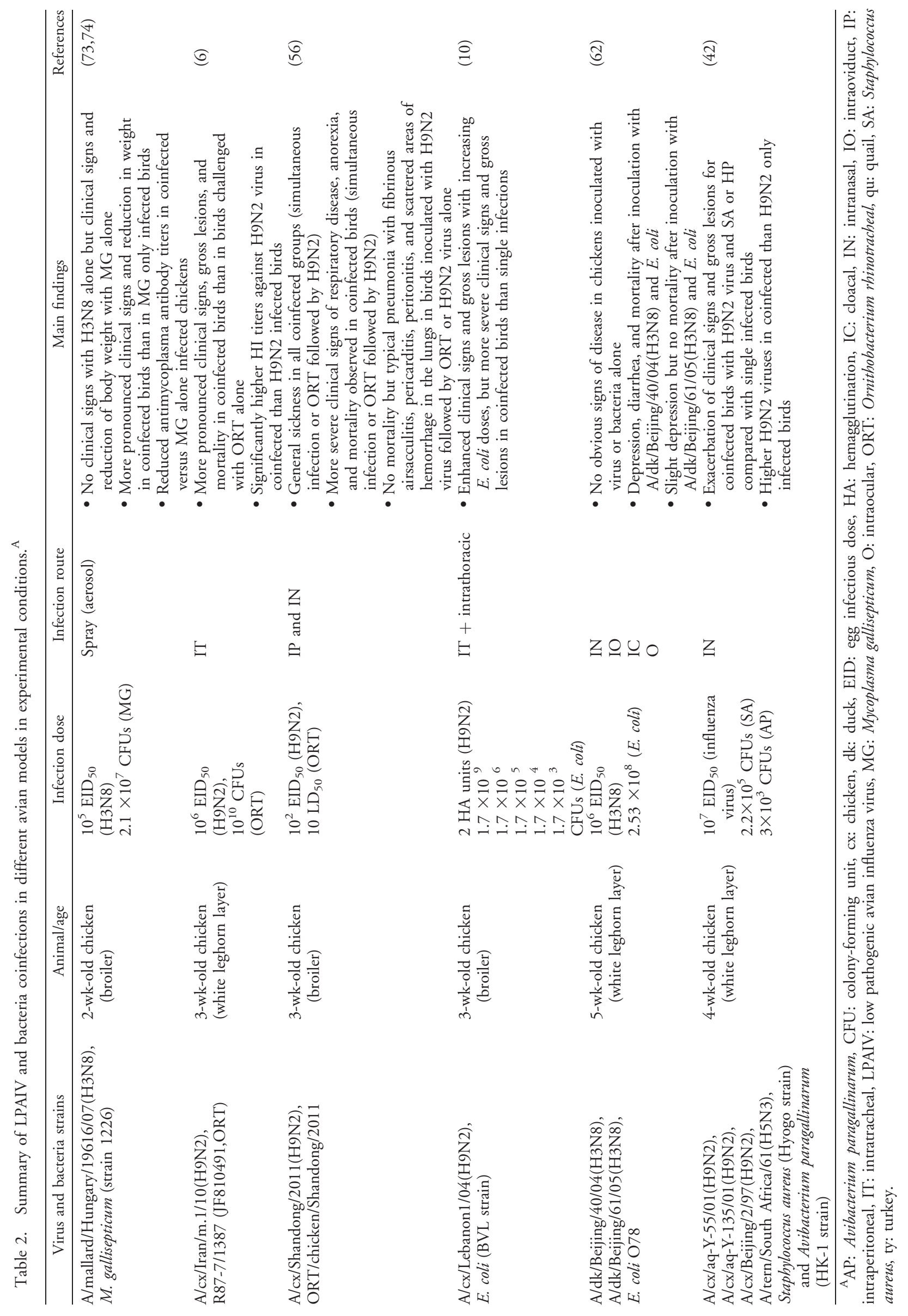


Viral interference is a phenomenon in which a cell infected by a virus does not allow replication of a second homologous or heterologous superinfectant virus (22). Viral interference can result from different mechanisms, including competing by attachment interference therefore reducing or blocking of receptor sites for the superinfecting virus, competing intracellularly for replication host machinery, and virus-induced interferon interference. NDV and LPAIV replicate in cells where there are trypsin-like enzymes such as in the upper respiratory and intestinal epithelia and might compete for the same target cells or replicate in adjacent cells (77). Both NDV and AIV bind to sialic acid-linked glycoconjugates on host cells and may also compete for host cell machinery during viral replication $(25,76)$. In addition, previous replication in the same site of another virus may affect replication by activating antiviral immune responses. Although the LaSota NDV strain is known to be a weak interferon inducer as part of their low virulent phenotype profile, local interferon production might still be able to interfere with LPAIV replication (23). In fact, previous studies in embryonated eggs showed that LaSota NDV could suppress growth of a H9N2 LPAIV, provided NDV was inoculated prior to LPAIV (28). Influenza virus-induced interferons may be the other possible reason for the inhibited replication of NDV (43). Viral interference has also been suggested in other studies with influenza virus in humans (H1N1). It was reported that increase in the proportion and number of rhinovirus can decrease influenza virus diagnoses in human, suggesting that rhinoviruses may compete with influenza virus for receptor binding and replication (4). Bacterial and viral coinfections usually show synergistic effects and exacerbate clinical signs and lesions. No competition between pathogens is observed then.

\section{TIMING OF COINFECTIONS}

In an attempt to put together the available methods reported in the literature for coinfections in experimental conditions, and mainly to see which time line may best fit field coinfections situations, we drew time arrows summarizing LPAIV and coinfecting bacteria experiments (Fig. 1) as well as LPAIV and coinfecting virus experiments (Fig. 2). The studies in experimental conditions conducted so far report either simultaneous infections (central parts of the figures, in the arrows), or subsequent infections usually 3 days apart (bacteria or virus followed by LPAIV, LPAIV followed by bacteria or virus on the top or bottom panel of the figures, respectively). The 3-day interval chosen between subsequent infections was pretty consistent throughout literature $(10,19$, $35,42,73,74)$. Just five studies compared in parallel simultaneous and subsequent infections with similar experimental conditions. Kishada and colleagues first studied LPAIV H9N2 and Avibacterium paragallinarum with simultaneous inoculation and SA infection followed by LPAIV H9N2 inoculation (42). The use of two different bacteria made a systematic comparison of the timing of coinfection difficult. Pan et al. coinfected chickens with LPAIV H9N2 and ORT and showed that when ORT was inoculated before or at the same time as LPAIV H9N2, the disease outcome was more severe (56). LPAIV (H7N2 in chickens or H3N8 in mallard) and NDV experimental coinfections have been more systematically studied $(19,25)$. While a minimal effect of the LPAIV and NDV coinfection was observed on a clinical point of view, an altered shedding pattern was detected in both mallards 


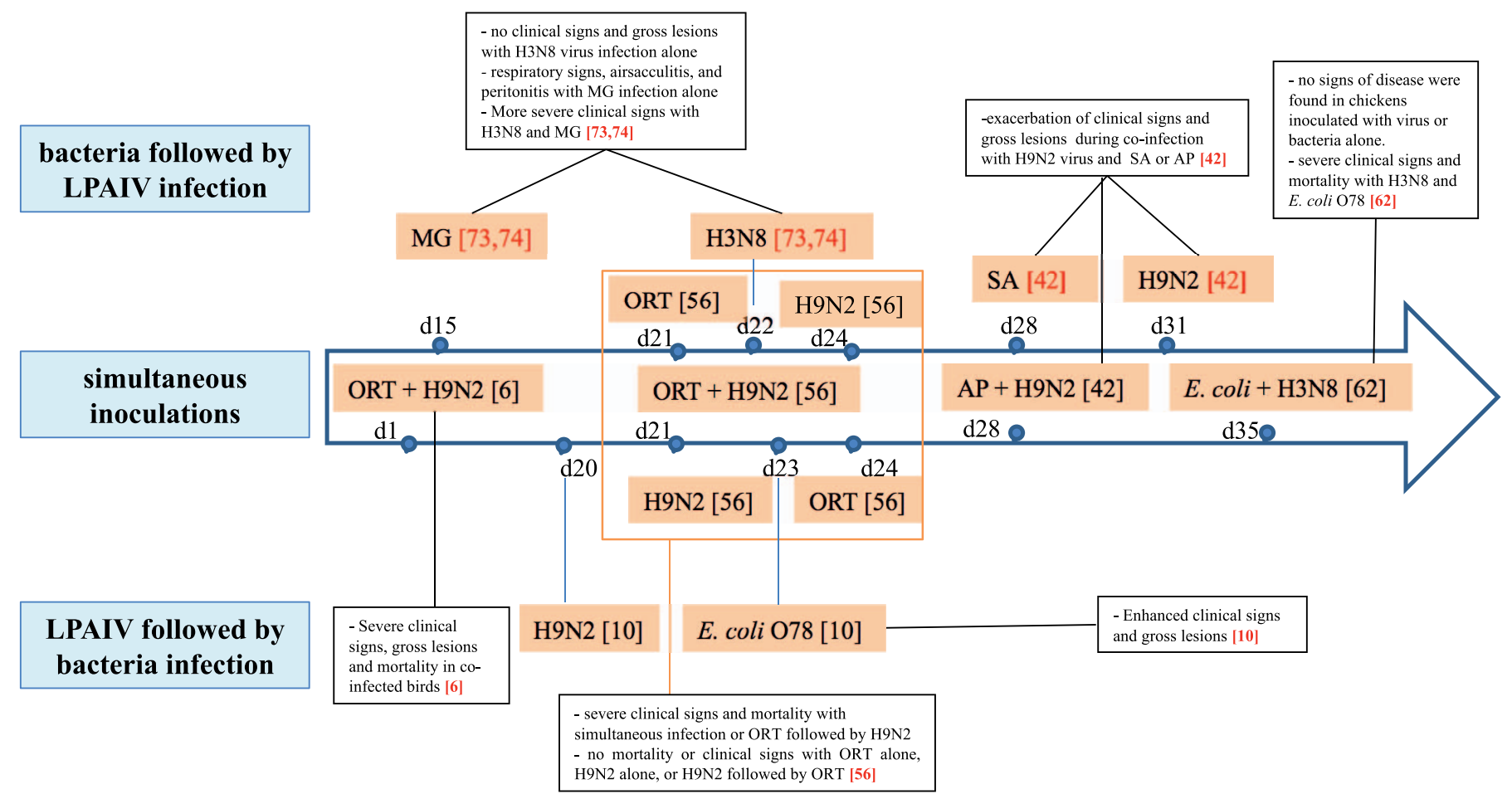

Fig. 1. Time arrow of LPAIV and bacteria coinfections in experimental conditions. AP: Avibacterium paragallinarum, d: day, LPAIV: low pathogenic avian influenza virus, MG: Mycoplasma gallisepticum, ORT: Ornithobacterium rhinotracheale, SA: Staphylococcus aureus.

and chickens, irrespective of the timing of the coinfection $(19,25)$. When LPAIV and IBV live vaccines were both administered to chickens, the coinfection led to more severe clinical signs and longer LPAIV shedding, again irrespective of the timing of coinfection (35). In the laboratory setting, the timing of coinfections therefore does not seem to play an essential role in pathogenesis. While common knowledge in virology associates coinfections with a virus coming first followed by a bacterium, the timing in the field may actually be opposite with commensal bacteria that are there first and may become a problem when a virus superinfects the birds (14). Manheimia haemolytica, Gallibacterium anatis, and Pseudomonas aeruginosa have indeed been identified as commensal bacteria of the upper respiratory tract of poultry, while they may also be found in sick birds either in the presence of a coinfecting pathogen or in difficult environmental conditions $(3,5,48,71)$.

\section{virus followed by LPAIV infection}

- no clinical signs in chickens for single and co-infections
- mild clinical signs in turkeys with or without NDV - mild clinical signs in turkeys with or without NDV - lower early virus shedding ( $2-3 \mathrm{dpi})$ but higher late virus
shedding [19]

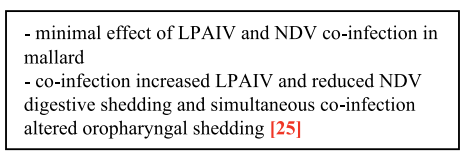

digestive shedding and simultaneous co-infection altered oropharyngal shedding $[25]$

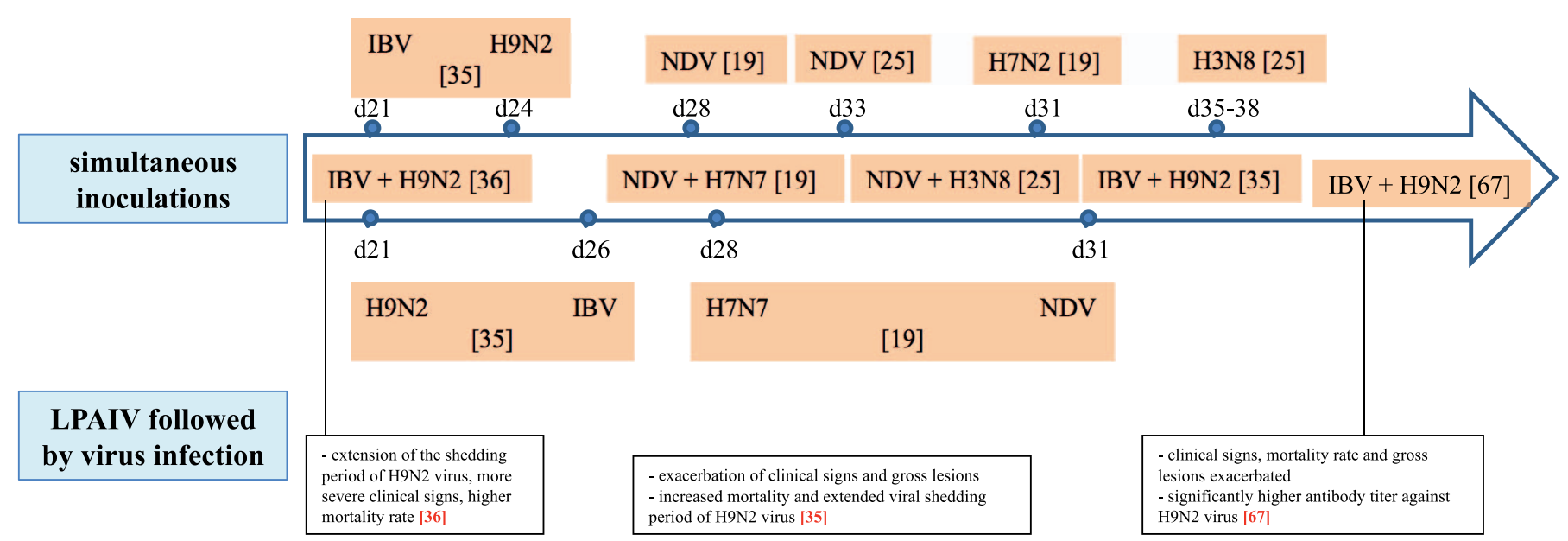

Fig. 2. Time arrow of LPAIV and avian virus coinfections in experimental conditions. d: day, IBV: infectious bronchitis virus, LPAIV: low pathogenic avian influenza virus, NDV: Newcastle disease virus. 


\section{SPF VERSUS COMMERCIAL BIRDS FOR EXPERIMENTAL INFECTIONS}

In chickens, to avoid interference with other pathogens and in an attempt to "standardize" experiments, researchers usually inoculate SPF birds. The absence (or very limited supply) of SPF turkeys, quail, and other poultry species makes it of course difficult: commercial birds are then used in experimental conditions. The SPF versus commercial bird (broiler, layer, or breeder) comparison for LPAIV infections (with or without complicating pathogens) has, however, never been properly investigated. The immune responses of two types of chickens have been compared to some extent in vaccine studies that aimed at understanding differences in vaccine protection in the laboratory and in the field $(30,38,65,81)$. These studies show a better antibody response of SPF chickens than commercial birds, likely due to the differences among genetic lines of chickens in antibody development.

To our knowledge a single study compared SPF and commercial birds for LPAIV pathogenicity. Ladman et al. (45) indeed observed respiratory signs, airsacculitis, and microscopic lesions in the trachea and lung of broilers infected with LPAIV H7N2 but very rarely in SPF layers. Systemic (serum) antibodies were also detected earlier in broilers than in SPF layers. The authors suggested that one rethink the choice of bird type for LPAIV pathogenesis studies. To mimic the field situation, commercial birds of course seem more appropriate also in experimental settings, but care should be taken to control the health status of the birds. Vaccination history should also be respected to be closer to the farm situation.

To study LPAIV pathogenesis to better understand disease outcome in the field, thought should be given to the design of experimental settings. Depending upon the research question asked, different protocols may be selected. In addition to the variables we have just reviewed, bird type, single infections or coinfections, timing, dose of infection(s), and environmental and management variables play a critical but poorly controlled role in the disease outcome in farms. Contaminated dust is a known source of respiratory pathogens, which is very difficult to reproduce in laboratory settings. One way to address the spread of respiratory pathogens with dust in experimental conditions is to inoculate birds by aerosol rather than IN or IT. In a clinical study, authors compared the $50 \%$ infectious dose $\left(\mathrm{ID}_{50}\right)$ by aerosol and $\mathrm{IN}$ inhalations and showed a 100 -fold lower $\mathrm{ID}_{50}$ in the first case (80). Access of virus particles to the deep air sacs is actually bypassed when birds are infected IN or IT. The use of aerosols for in vivo infections may help reduce the gap between the laboratory and the field. Temperature and humidity can now also be regulated (and brought closer to the farm conditions) in poultry isolators with relevant technicity. All these improvements in experimental conditions will contribute to bringing laboratory settings closer to the field situation, but one should stay aware of the remaining gap between the two configurations and not overinterpret experimental results.

\section{CONCLUSION}

Taken together, this review of literature suggests that to study coinfections with LPAIV and a complicating pathogen in experimental conditions, using young (3-4 wk-old) birds, $10^{6}$ $\mathrm{EID}_{50}$ of virus, and $10^{6-9} \mathrm{CFU}$ of bacteria per bird, IN, would most likely lead to clinical observations and would allow for better comparison of the findings with previously published studies. While using SPF birds (for chickens) makes comparison with published data easier, commercial birds with a carefully checked health status better reflect the field situation and may be even more susceptible to infections than their SPF counterparts. Further studies are warranted to truly assess the cost benefit of using commercial birds and to determine the adequate timing of the coinfection in relation to the field situations. Environmental factors (temperature, relative humidity, ammonia level, etc.) should also be taken into account because they definitely play a role in the field but have so far not been much looked at in experimental settings.

\section{REFERENCES}

1. Alexander, D. J. A review of avian influenza in different bird species. Vet. Microbiol. 74:3-13. 2000.

2. Alexander, D. J. Report on avian influenza in the Eastern Hemisphere during 1997-2002. Avian Dis. 47:792-797. 2003.

3. Ali, A., N. Siddique, M.A. Abbas, A. Ghafar, S. Rafique, R. Ali, A. U. R. Memon, and K. Naeem. Role of Mannheimia (Pasteurella) haemolytica in severe respiratory tract infection in commercial poultry in Pakistan. Pak. Vet. J. 35:279-282. 2015.

4. Ånestad, G., and S. A. Nordbø. Virus interference. Did rhinoviruses activity hamper the progress of the 2009 influenza A (H1N1) pandemic in Norway? Med. Hypotheses 77:1132-1134. 2011.

5. Antiabong, J., E. Haruna, J. Owolodun, B. Yakubu, M. Odugbo, I. Suleiman, S. Ekundayo, and P. Dalyop. Isolation of Mannheimia (Pasteurella) haemolytica serotypes a2 and a12 from clinically ill and dead chickens: a case report. Trop. Vet. 23:61-64. 2006.

6. Azizpour, A., H. Goudarzi, M. Banani, A. Nouri, R. Momayez, M. H. Hablolvarid, M. Mohammad Abdoshah, and P. Bijanzad. Evaluation of clinical signs, gross lesions and antibody response in experimental of individual and co-infection of $\mathrm{H} 9 \mathrm{~N} 2$ avian influenza and Ornithobacterium rhinotracheale in SPF chickens. Eur. J. Exp. Biol. 3:503-507. 2013.

7. Banks, J., E. C. Speidel, P. A. Harris, and D. J. Alexander. Phylogenetic analysis of influenza A viruses of $\mathrm{H} 9$ haemagglutinin subtype. Avian Pathol. 29:353-359. 2000.

8. Bano, S., K. Naeem, and S. A. Malik. Evaluation of pathogenic potential of avian influenza virus serotype H9N2 in chickens. Avian Dis. 47:817-822. 2003.

9. Barbour, E. K., R. G. El-Hakim, M. S. Kaadi, H. A. Shaib, D. D. Gerges, and P. A. Nehme. Evaluation of the histopathology of the respiratory system in essential oil treated broilers following a challenge with Mycoplasma gallisepticum and/or H9N2 influenza virus. Int. J. App. Res. Vet. Med. 4:293-300. 2006.

10. Barbour, E. K., A. M. F. A. Mastori, Abdel Nour, H. A. Shaib, L. S Jaber, R. H. Yaghi, A. Sabra, F. T. Sleiman, R. K. Sawaya, A. Niedzwieck, I. T. Tayeb, Z. G. Kassaify, M. Rath, S. Harakeh, and K. E. Barbour. Standardization of a new model of H9N2/Escherichia coli challenge in broilers in the Lebanon. Vet. Ital. 45:317-322. 2009.

11. Bertran, K., R. Dolz, N. Busquets, V. Gamino, J. Vergara-Alert, A. J. Chaves, A. Ramis, F. X. Abad, U. Höfle, and N. Majó. Pathobiology and transmission of highly and low pathogenic avian influenza viruses in European quail (Coturnix c. coturnix). Vet. Res. 44:23. 2013.

12. Bertran, K., E. Pérez-Ramírez, N. Busquets, R. Dolz, A. Ramis, A. Darji, F. X. Abad, R. Valle, A. Chaves, J. Vergara-Alert, M. Barral, U. Höfle, and N. Majó. Pathogenesis and transmissibility of highly (H7N1) and low $(\mathrm{H} 7 \mathrm{~N} 9)$ pathogenic avian influenza virus infection in red-legged partridge (Alectoris rufa). Vet. Res. 42:24. 2011.

13. Bonfante, F., L. V. Patrono, R. Aiello, M. S. Beato, C. Terregino, and I. Capua. Susceptibility and intra-species transmission of the H9N2 G1 prototype lineage virus in Japanese quail and turkeys. Vet. Microbiol. 165:177-183. 2013.

14. Bosch, A. A. T. M., G. Biesbroek, K. Trzcinski, E. A. M. Sanders, and D. Bogaert. Viral and bacterial interactions in the upper respiratory tract. PLoS Pathog. 9:e1003057. 2013. 
15. Brown, J. D., R. D. Berghaus, T. P. Costa, R. Poulson, D. L. Carter, C. Lebarbenchon, and D. E. Stallknecht. Intestinal excretion of a wild bird-origin $\mathrm{H} 3 \mathrm{~N} 8$ low pathogenic avian influenza virus in mallards (Anas platyrhynchos). J. Wildl. Dis. 48:991-998. 2012.

16. Capua, I., and D. J. Alexander. Avian influenza: recent developments. Avian Pathol. 33:393-404. 2004.

17. Capua, I., and S. Marangon. The avian influenza epidemic in Italy, 1999-2000: a review. Avian Pathol. 29:289-294. 2000.

18. Costa, T. P., J. D. Brown, E. W. Howerth, and D. E. Stallknecht. Variation in viral shedding patterns between different wild bird species infected experimentally with low-pathogenicity avian influenza viruses that originated from wild birds. Avian Pathol. 40:119-124. 2011.

19. Costa-Hurtado, M., C. L. Afonso, P. J. Miller, E. Spackman, D. R. Kapczynski, D. E. Swayne, E. Shepherd, D. Smith, A. Zsak, and M. PantinJackwood. Virus interference between H7N2 low pathogenic avian influenza virus and lentogenic Newcastle disease virus in experimental co-infections in chickens and turkeys. Vet. Res. 45:1. 2014.

20. Daoust, P.-Y., M. van de Bildt, D. van Riel, G. van Amerongen, T. Bestebroer, R. Vanderstichel, R. A. M. Fouchier, and T. Kuiken. Replication of 2 subtypes of low-pathogenicity avian influenza virus of duck and gull origins in experimentally infected Mallard ducks. Vet. Pathol. 50:548-559. 2013.

21. Degen, W. G. J., J. Smith, B. Simmelink, E. J. Glass, D. W. Burt, and V. E. J. C. Schijns. Molecular immunophenotyping of lungs and spleens in naive and vaccinated chickens early after pulmonary avian influenza A (H9N2) virus infection. Vaccine 24:6096-6109. 2006.

22. Dianzani, F. Viral interference and interferon. Ric. Clin. Lab. 5:196-213. 1975.

23. Dortmans, J. C., G. Koch, P. J. Rottier, and B. P. Peeters. Virulence of Newcastle disease virus: what is known so far? Vet. Res. 42: 122. 2011.

24. El Zowalaty, M. E., Y. Chander, P. T. Redig, H. K. Abd El Latif, M. A. El Sayed, and S. M. Goyal. Selective isolation of avian influenza virus (AIV) from cloacal samples containing AIV and Newcastle disease virus. J. Vet. Diagn. Invest. 23:330-332. 2011.

25. França, M., E. W. Howerth, D. Carter, A. Byas, R. Poulson, C. L. Afonso, and D. E. Stallknecht. Co-infection of mallards with low-virulence Newcastle disease virus and low-pathogenic avian influenza virus. Avian Pathol. 43:96-104. 2014.

26. Freeman, S., and J.C. Herron. Evolutionary analysis, 4th ed. Pearson Education International, Washington, NJ. 2007.

27. Furuse, Y., A. Suzuki, M. Kishi, N. Nukiwa, M. Shimizu, R. Sawayama, N. Fuji, and H. Oshitani. Occurrence of mixed populations of influenza A viruses that can be maintained through transmission in a single host and potential for reassortment. J. Clin. Microbiol. 48:369-374. 2010.

28. Ge, S., D. Zheng, Y. Zhao, H. Liu, W. Liu, Q. Sun, J. Li, S. Yu, Y. Zuo, X. Han, L. Li, Y. Lv, Y. Wang, X. Liu, and Z. Wang. Evaluating viral interference between influenza virus and Newcastle disease virus using realtime reverse transcription-polymerase chain reaction in chicken eggs. Virol. J. 9:128. 2012.

29. Gharaibeh, S. Pathogenicity of an avian influenza virus serotype H9N2 in chickens. Avian Dis. 52:106-110. 2008.

30. Gharaibeh, S., and S. Amareen. Vaccine efficacy against a new avian influenza (H9N2) field isolate from the Middle East (serology and challenge studies). Avian Dis. 59:508-511. 2015.

31. Gou, Y., J. Xie, and M. Wang. A strain of influenza A H9N2 virus repeatedly isolated from human population in China. Zhonghua Shi Yan $\mathrm{He}$ Lin Chuang Bing Du Xue Za Zhi 14:209-212 (in Chinese). 2000.

32. Graham, J. P., J. J. Boland, and E. Silbergeld. Growth promoting antibiotics in food animal production: an economic analysis. Public Health Rep. 122:79-87. 2007.

33. Guan, Y., K. F. Shortridge, S. Krauss, P. S. Chin, K. C. Dyrting, T. M. Ellis, R. G. Webster, and M. Peiris. H9N2 influenza viruses possessing $\mathrm{H} 5 \mathrm{~N} 1$-like internal genomes continue to circulate in poultry in southeastern China. J. Virol. 74:9372-9380. 2000.

34. Hadipour, M. M., S.Farjadian, F. Azad, N. Sheibani, and A. Olyaie. Histologic lesions of thymus and bursa of fabricius in commercial broiler chickens inoculated with H9N2 avian influenza virus. Int. J. Anim. Vet. Adv. 3:186-188. 2011.
35. Haghighat-Jahromi, M., K. Asasi, H. Nili, and H. Dadras. Role of infectious bronchitis live vaccine on pathogenicity of H9N2 avian influenza virus. Int. J. Poult. Sci. 6:838-841. 2007.

36. Haghighat-Jahromi, M., K. Asasi, H. Nili, H. Dadras, and A. H. Shooshtari. Coinfection of avian influenza virus (H9N2 subtype) with infectious bronchitis live vaccine. Arch. Virol. 153:651-655. 2008.

37. He, C.-Q., Z.-X. Xie, G.-Z. Han, J.-B. Dong, D. Wang, J.-B. Liu, L.-Y. Ma, X.-F. Tang, X.-P. Liu, Y.-S. Pang, and G.-R. Li. Homologous recombination as an evolutionary force in the avian influenza A virus. Mol. Biol. Evol. 26:177-187. 2009.

38. Heine, H. G., A. J. Foord, P. L. Young, P. T. Hooper, P. R. Lehrbach, and D. B. Boyle. Recombinant fowlpox virus vaccines against Australian virulent Marek's disease virus: gene sequence analysis and comparison of vaccine efficacy in specific pathogen free and production chickens. Virus Res. 50:23-33. 1997.

39. Iqbal, M., T. Yaqub, N. Mukhtar, M. Z. Shabbir, and J. W. McCauley. Infectivity and transmissibility of $\mathrm{H} 9 \mathrm{~N} 2$ avian influenza virus in chickens and wild terrestrial birds. Vet. Res. 44:100. 2013.

40. Iqbal, M., T. Yaqub, K. Reddy, and J. W. McCauley. Novel genotypes of H9N2 influenza A viruses isolated from poultry in Pakistan containing NS genes similar to highly pathogenic $\mathrm{H} 7 \mathrm{~N} 3$ and $\mathrm{H} 5 \mathrm{~N} 1$ viruses. PLoS ONE 4:e5788. 2009.

41. Jones, Y. L., and D. E. Swayne. Comparative pathobiology of low and high pathogenicity H7N3 Chilean avian influenza viruses in chickens. Avian Dis. 48:119-128. 2004.

42. Kishida, N., Y. Sakoda, M. Eto, Y. Sunaga, and H. Kida. Coinfection of Staphylococcus aureus or Haemophilus paragallinarum exacerbates H9N2 influenza A virus infection in chickens. Arch. Virol. 149:2095-2104. 2004.

43. Kreijtz, J. H. C. M., R. A. M. Fouchier, and G. F. Rimmelzwaan. Immune responses to influenza virus infection. Virus Res. 162:19-30. 2011.

44. Ladman, B. S., C. P. Driscoll, C. R. Pope, R. D. Slemons, and J. Gelb. Potential of low pathogenicity avian influenza viruses of wild bird origin to establish experimental infections in turkeys and chickens. Avian Dis. 54:1091-1094. 2010.

45. Ladman, B. S., S. C. Rosenberger, J. K. Rosenberger, C. R. Pope, and J. Gelb. Virulence of low pathogenicity H7N2 avian influenza viruses from the Delmarva peninsula for broiler and leghorn chickens and turkeys. Avian Dis. 52:623-631. 2008.

46. Li, K. S., Y. Guan, J. Wang, G. J. D. Smith, K. M. Xu, L. Duan, A. P. Rahardjo, P. Puthavathana, C. Buranathai, T. D. Nguyen, A. T. S. Estoepangestie, A. Chaisingh, P. Auewarakul, H. T. Long, N. T. H. Hanh, R. J. Webby, L. L. M. Poon, H. Chen, K. F. Shortridge, K. Y. Yuen, R. G. Webster, and J. S. M. Peiris. Genesis of a highly pathogenic and potentially pandemic H5N1 influenza virus in eastern Asia. Nature 430:209-213. 2004.

47. Mo, I. P., M. Brugh, O. J. Fletcher, G. N. Rowland, and D. E. Swayne. Comparative pathology of chickens experimentally inoculated with avian influenza viruses of low and high pathogenicity. Avian Dis. 41:125136. 1997.

48. Mrden, M., M. Velhner, I. Kovincic, and M. Gagic. Prevalence and the results of experimentally induced pseudomoniasis in chicks. Peradarstovo 23:295-298. 1998.

49. Muhammad, K., I. Hussan, A. Riaz, R. Manzoor, and M. A. Sajid. Isolation and characterization of avian influenza virus (H9 type) from outbreaks of respiratory syndrome in commercial poultry. Pak. J. Sci. Res. 53:3-4. 2001.

50. Muramoto, Y., T. Noda, E. Kawakami, R. Akkina, and Y. Kawaoka. Identification of novel influenza A virus proteins translated from PA mRNA. J. Virol. 87:2455-2462. 2013.

51. Naeem, K., and N. Siddique. Use of strategic vaccination for the control of avian influenza in Pakistan. Dev. Biol. (Basel) 124:145-150. 2006

52. Nili, H., and K. Asasi. Avian influenza (H9N2) outbreak in Iran. Avian Dis. 47:828-831. 2003.

53. Nili, H., and K. Asasi. Natural cases and an experimental study of H9N2 avian influenza in commercial broiler chickens of Iran. Avian Pathol. 31:247-252. 2002. 
54. Nili, H., A. Mohammadi, H. Habibi, and S. Firouzi. Pathogenesis of H9N2 virus in Chukar partridges. Avian Pathol. 42:230-234. 2013.

55. Nouri, A., K. Assasi, and M. R. Seyfi-abad Shapouri. Field study of infectious bronchitis virus in broiler using type-specific RT-PCR. Arch. Razi Inst. 55:1-9. 2003.

56. Pan, Q., A. Liu, F. Zhang, Y. Ling, C. Ou, N. Hou, and C. He. Co-infection of broilers with Ornithobacterium rhinotracheale and H9N2 avian influenza virus. BMC Vet. Res. 8:104. 2012.

57. Pantin-Jackwood, M. J., D. M. Smith, J. L. Wasilenko, and E. Spackman. Low pathogenicity avian influenza viruses infect chicken layers by different routes of inoculation. Avian Dis. 56:276-281. 2012.

58. Pantin-Jackwood, M. J., J. L. Wasilenko, E.Spackman, D. L Suarez, and D. E. Swayne. Susceptibility of turkeys to pandemic-H1N1 virus by reproductive tract insemination. Virol. J. 7:27. 2010.

59. Peng, Y., Z. Xie, J. Liu, Y. Pang, X. Deng, Z. Xie, L. Xie, Q. Fan, and S. Luo. Epidemiological surveillance of low pathogenic avian influenza virus (LPAIV) from poultry in Guangxi Province, Southern China. PLoS ONE 8:e77132. 2013.

60. Perez, D. R., W. Lim, J. P. Seiler, G. Yi, M. Peiris, K. F. Shortridge, and R. G. Webster. Role of quail in the interspecies transmission of $\mathrm{H} 9$ influenza A viruses: molecular changes on HA that correspond to adaptation from ducks to chickens. J. Virol. 77:3148-3156. 2003.

61. Petersen, H., M. Matrosovich, S. Pleschka, and S. Rautenschlein. Replication and adaptive mutations of low pathogenic avian influenza viruses in tracheal organ cultures of different avian species. PLoS ONE 7:e42260. 2012.

62. Pu, J., Y. L. Fan, Z. Wang, B. Ma, E. G. Brown, and J. H. Liu. Pathogenicity of H3N8 influenza viruses isolated from domestic ducks in chickens with or without Escherichia coli coinfections. Avian Dis. 56:597600. 2012.

63. Qi, X., D. Tan, C. Wu, C. Tang, T. Li, X. Han, J. Wang, C. Liu, R. Li, and J. Wang. Deterioration of eggshell quality in laying hens experimentally infected with H9N2 avian influenza virus. Vet. Res. 47:35. 2016.

64. Rott, R. The pathogenic determinant of influenza virus. Vet. Microbiol. 33:303-310. 1992.

65. Sasaki, T., N. Kokumai, T. Ohgitani, T. Imamura, A. Sawata, Z. Lin, Y. Sakoda, and H. Kida. A comparison of the antibody responses between specific pathogen-free and commercial layers immunized with an influenza vaccine prepared from inactivated non-pathogenic $\mathrm{H} 5 \mathrm{~N} 1$ virus by single shot. J. Vet. Med. Sci. 72:819-821. 2010.

66. Seifi, S., K. Asasi, and A. Mohammadi, A. Natural co-infection caused by avian influenza $\mathrm{H} 9$ subtype and infectious bronchitis viruses in broiler chicken farms. Vet. Arch. 80:269-281. 2010.

67. Seifi, S., K. Asasi, and A. Mohammadi. An experimental study on broiler chicken co-infected with the specimens containing avian influenza (H9 subtype) and infectious bronchitis (4/91 strain) viruses. Iranian J. Vet. Res. 13:138-142. 2012.

68. Shaib, H. A., N. Cochet, T. Ribeiro, A. M. Abdel Nour, G. Nemer, and E. K. Barbour. Impact of embryonic passaging of H9N2 virus on pathogenicity and stability of HA1-amino acid sequence cleavage site. Med. Sci. Monit. 16:BR333-337. 2010.

69. Shortridge, K. F., N. N. Zhou, Y. Guan, P. Gao, T. Ito, Y. Kawaoka, S. Kodihalli, S. Krauss, D. Markwell, K. G. Murti, M. Norwood, D. Senne, L. Sims, A. Takada, and R. G. Webster. Characterization of avian H5N1 influenza viruses from poultry in Hong Kong. Virology 252:331342. 1998.

70. Sid, H., K. Benachour, and S. Rautenschlein. Co-infection with multiple respiratory pathogens contributes to increased mortality rates in Algerian poultry flocks. Avian Dis. 59:440-446. 2015.

71. Singh, S. V., B. R. Singh, D. K. Sinha, V. O. R. Kumar, and P. A. Vadhana. Gallibacterium anatis: An emerging pathogen of poultry birds and domiciled birds. J. Vet. Sci. Tech. 7:324. 2016. doi:10.4172/2157-7579. 1000324.
72. Spackman, E., J. Gelb, L. A. Preskenis, B. S. Ladman, C. R. Pope, M. J. Pantin-Jackwood, and E. T. McKinley. The pathogenesis of low pathogenicity $\mathrm{H} 7$ avian influenza viruses in chickens, ducks and turkeys. Virol. J. 7:331. 2010.

73. Stipkovits, L., L. Egyed, V. Palf, A. Beres, E. Pitlik, M. Somogyi, S. Szathmary, and B. Denes. Effect of low-pathogenicity influenza virus H3N8 infection on Mycoplasma gallisepticum infection of chickens. Avian Pathol. 41:51-57. 2012.

74. Stipkovits, L., R. Glavits, V. Palfi, A. Beres, L. Egyed, B. Denes, M. Somogyi, and S. Szathmary. Pathologic lesions caused by coinfection of Mycoplasma gallisepticum and H3N8 low pathogenic avian influenza virus in chickens. Vet. Pathol. 49:273-283. 2012.

75. Subtain, S. M., Z. A. Chaudhry, A. A. Anjum, A. Maqbool, and U. Sadique. Study on pathogenesis of low pathogenic avian influenza virus $\mathrm{H} 9$ in broiler chickens. Pak. J. Zool. 43:999-1008. 2011.

76. Suzuki, Y. Receptor and molecular mechanism of the host range variation of influenza viruses. Uirusu 51:193-200 (in Japanese). 2001.

77. Swayne, D. E., and D. A. Halvorson. Influenza. In Diseases of poultry, 12th ed. Y. M. Saif, J. R. Glisson, L. R. McDougald, L. K. Nolan, D. E. Swayne, eds. Blackwell Publishing, Ames, IA. pp. 153-184. 2008.

78. Swayne, D. E., and M. Pantin-Jackwood. Pathogenicity of avian influenza viruses in poultry. Dev. Biol. (Basel) 124:61-67. 2006.

79. Swayne, D. E., D. A. Senne, and C. W. Beard. Isolation and identification of avian pathogens, 4th ed. American Association of Avian Pathology, Georgia, PA. 1998.

80. Tellier, R. Review of aerosol transmission of influenza A virus. Emerg. Inf. Dis. 12:1657-1662. 2006.

81. Terregino, C., A. Toffan, M. S. Beato, R. De Nardi, M. Vascellari, A. Meini, G. Ortali, M. Mancin, and I. Capua. Pathogenicity of a QX strain of infectious bronchitis virus in specific pathogen free and commercial broiler chickens, and evaluation of protection induced by a vaccination programme based on the Ma5 and 4/91 serotypes. Avian Pathol. 37:487493. 2008.

82. Tong, S., X. Zhu, Y. Li, M. Shi, J. Zhang, M. Bourgeois, H. Yang, X. Chen, S. Recuenco, J. Gomez, L.-M. Chen, A. Johnson, Y. Tao, C. Dreyfus, W. Yu, R. McBride, P. J. Carney, A. T. Gilbert, J. Chang, Z. Guo, C. T. Davis, J. C. Paulson, J. Stevens, C. E. Rupprecht, E. C. Holmes, I. A. Wilson, and R. O. Donis. New World bats harbor diverse influenza A viruses. PLoS Pathog. 9:e1003657. 2013.

83. Wang, J., C. Tang, Q. Wang, R. Li, Z. Chen, X. Han, J. Wang, and $\mathrm{X}$. Xu. Apoptosis induction and release of inflammatory cytokines in the oviduct of egg-laying hens experimentally infected with H9N2 avian influenza virus. Vet. Microbiol. 177:302-314. 2015.

84. Webster, R. G., W. J. Bean, O. T. Gorman, T. M. Chambers, and Y. Kawaoka. Evolution and ecology of influenza A viruses. Microbiol. Rev. 56:152-179. 1992.

85. Wood, G. W., J. W. McCauley, J. B. Bashiruddin, and D. J. Alexander. Deduced amino acid sequences at the haemagglutinin cleavage site of avian influenza A viruses of $\mathrm{H} 5$ and $\mathrm{H} 7$ subtypes. Arch. Virol. 130:209-217. 1993.

86. World Animal Health Organisation (OIE). Global influenza program surveillance network. Evolution of $\mathrm{H} 5 \mathrm{~N} 1$ avian influenza viruses in Asia. Emerg. Inf. Dis. 11:1515-1521. 2005.

87. Yee, K. S., C. J. Cardona, and T. E. Carpenter. Transmission of low-pathogenicity avian influenza virus of subtype H6N2 from chickens to Pekin ducks and Japanese quail (Coturnix coturnix japonica). Avian Pathol. 38:59-64. 2009.

88. Yee, K. S., T. E. Carpenter, T. B. Farver, and C. J. Cardona. An evaluation of transmission routes for low pathogenicity avian influenza virus among chickens sold in live bird markets. Virology 394:19-27. 2009.

89. Ziegler, A. F., S. Davison, H. Acland, and R. J. Eckroade. Characteristics of $\mathrm{H} 7 \mathrm{~N} 2$ (nonpathogenic) avian influenza virus infections in commercial layers, in Pennsylvania, 1997-98. Avian Dis. 43:142-149. 1999. 